\title{
FOLLICLE FORMATION IN GUINEA-PIGS AND RABBITS: A COMPARATIVE STUDY WITH NOTES ON THE RETE OVARII
}

\author{
RUTH DEANESLY \\ A.R.C. Institute of Animal Physiology, Babraham, Cambridge
}

(Received 3rd March 1975)

At the end of the meiotic prophase, oocytes are enclosed by adjacent cells to form primordial follicles. Agreement is lacking on the origin of these cells, sometimes seen as epithelial, but in papers on man (Sauramo, 1954), the mouse (Peters \& Pedersen, 1967), the rabbit (Peters et al., 1965) and the ferret (Deanesly, 1970) they have been clearly described as stromal cells which have ramified among the oocytes from the earliest stages of ovarian development. At first these cells are flattened but they become cuboid and their nuclei enlargea transition readily seen in the rabbit and ferret (see Deanesly, 1970: Figs 20 and 21).

Recently, it has been suggested by Byskov \& Lintern-Moore (1973) and Peters (1973) that the rete tubules within the mouse ovary contribute cells to the formation of follicles and differentiate into granulosa cells. For reasons given below, this theory of early follicular development cannot be satisfactorily applied to other mammalian species studied. In the ferret ovary, the frequent presence of oocytes in the small rete tubules towards the end of meiosis, first described by Deanesly (1970), is by no means evidence of a contribution from the distinctive rete epithelium to primordial follicle formation.

The ovarian rete develops in the gonadal blastema from an early stage (see Kohn, 1926; Torrey, 1947). It does not derive from the coelomic surface epithelium, but spreads from the hilar area into the medulla. In the post-natal ferret ovary, active differentiation and proliferation of the rete coincided with the later stages of the meiotic prophase and the degeneration of many oocytes, both in the cortex and the medulla. During early development in the ferret, numerous oogonia were carried into the ovarian medulla and gave rise to oocytes which passed into various meiotic stages and were taken up by rete tubules, as were some of the oocytes degenerating in the cortex. They differed in size and appearance from the oocytes of newly formed primordial follicles. None of the follicles showed immediate growth and increase in numbers of granulosa cells unlike some in the guinea-pig and rabbit. There were no indications that the rete tubules contributed to follicle formation or growth in the ferret.

For comparison with the ferret and mouse, early stages of follicular and rete development have now been examined in guinea-pig and rabbit ovaries, fixed 
with their adjacent tissues in Bouin's fluid, serially sectioned at $7 \mu \mathrm{m}$ and stained with haematoxylin and eosin or periodic acid-Schiff.

The guinea-pig has a 68-day pregnancy; meiosis begins at about Day 35 and the first primordial follicles appear on Day 48 (Bookhout, 1945; Ioannou, 1964). Fifteen ovaries were examined from twelve fetal and post-partum guineapigs. In sections through whole embryos, rudiments of the rete could be seen by Day 26 in the hilar area, and again at Day 35 when the cells of the developing tubules had more darkly staining nuclei than those of the adjacent stroma. Some of the inner oocytes, already in meiosis, were in contact with the tubules but this did not apply to the main masses of cortical oocytes. At 44 and 49 days, besides the compact group of hilar rete tubules (Pl. 1, Fig. 5) there were other less well-defined tubules in the medulla, at first lacking a lumen, but distinguishable by the staining of the epithelium and the nucleoli present in the oval nuclei. These tubules were similar in size to those in the hilus and did not resemble the medullary tubules in the ferret and rabbit. Small oocytes were present in coiling hilar and medullary rete tubules as well as in the stroma ( $\mathrm{Pl}$. 1, Fig. 1).

On Day 49 of pregnancy, primordial follicles showing the transition from flattened stromal to cuboid pregranulosa cells were numerous, and some follicles, near the medulla, but not in contact with rete tubules, were already enlarging. Growing follicles with one to two layers of early granulosa cells were pear-shaped, with stromal cells apparently attaching to them at the exterior (Pl. 1, Figs 2, 3 and 4). There were no indications of cell transfers to follicles from adjacent rete tubules. Up to Day 51, cell divisions were rare in growing follicles; they were rather more common on Day 52, although attachment of stromal cells was still occurring. Few medullary rete tubules were distinguishable by Day 52, but the hilar tubules remained conspicuous for some weeks after birth (Pl. 1, Fig. 6). Small oocytes could be seen in them and also primordial follicles, probably degenerating. Ioannou (1964) estimated, from counts, that about $87 \%$ of oocytes degenerated during and after the meiotic prophase in the guinea-pig.

Rabbit ovaries at $20,24,25,28,35,50$ and 55 days post partum were examined in serial sections. By 20 days the post-natal meiotic prophase was effectively over, but meiotic stages and obviously degenerating oocytes could still be seen. Other unenclosed oocytes were present both in the medullary stroma and in rete tubules which were developing in the hilar area and spreading through the

\section{EXPLANATION OF PLATE 1}

\section{Guinea-pig fetal and neonatal ovaries.}

FIG. 1. Ovary at Day 44 of gestation. Oocytes are in meiosis among large darkly staining medullary rete tubules, lacking a lumen (arrowed). $\times 296$.

Fig. 2. Fetal ovary at Day 49 , showing an early follicle enlarging by aggregation of stromal cells: primordial follicles above. $\times 324$.

FIGs 3 and 4. Fetal ovary at Day 51 showing follicles growing by stromal aggregation. $\times 324$.

Fig. 5. Ovary at Day 52 of gestation showing cortex, medulla and mass of hilar rete tubules at bottom right. $\times 36$.

FIG. 6. Ovary at 22 days post partum showing hilar rete tubules containing oocytes. $\times 296$. 
Pl. NIF: 1

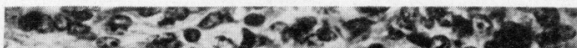

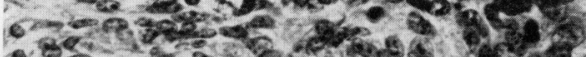

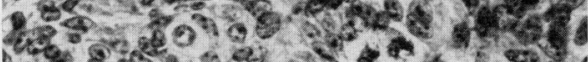

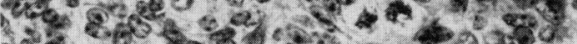

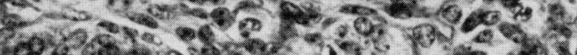

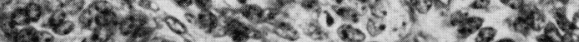

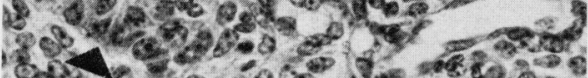

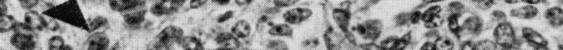

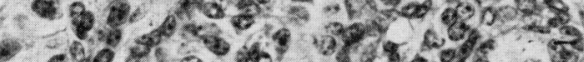

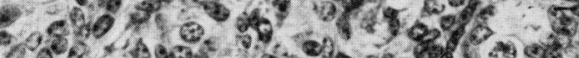

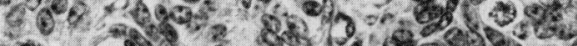

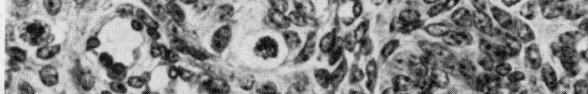

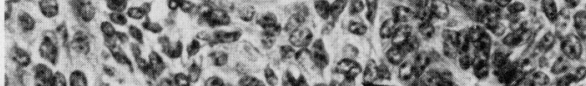

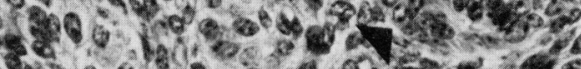

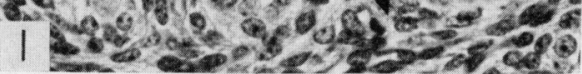

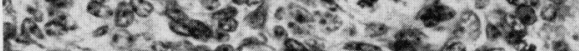
in 8 s.

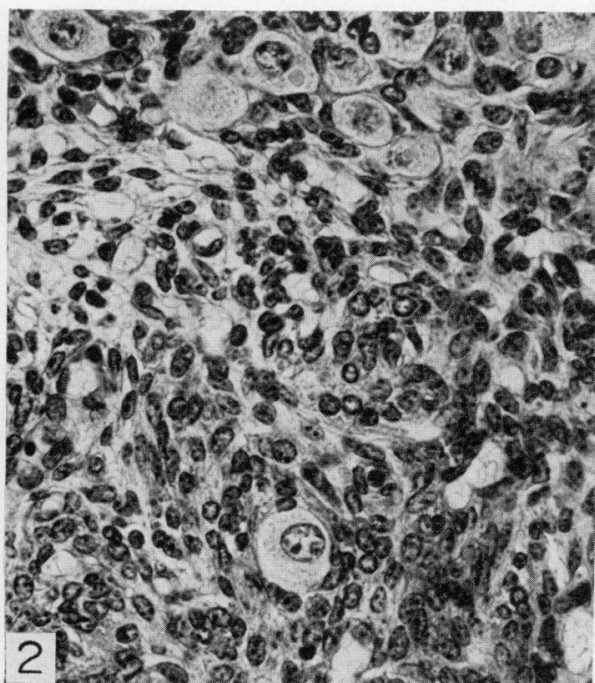

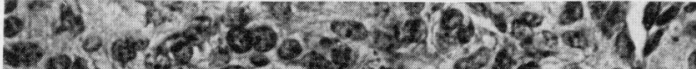
f.

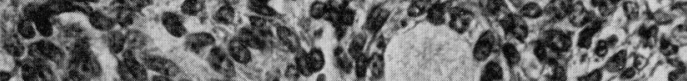

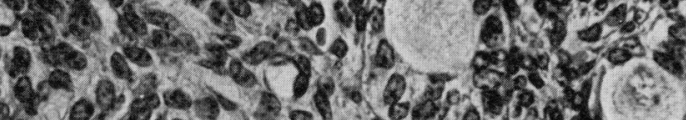

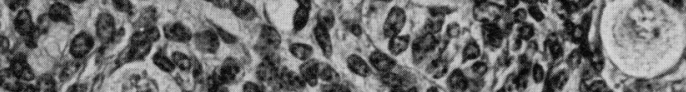

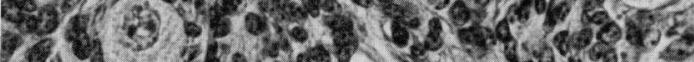

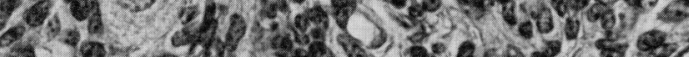
7.

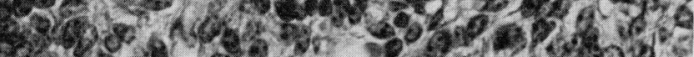

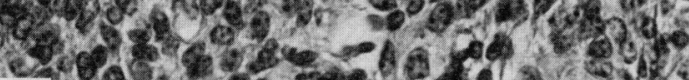

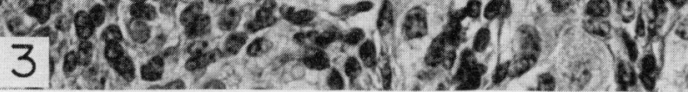

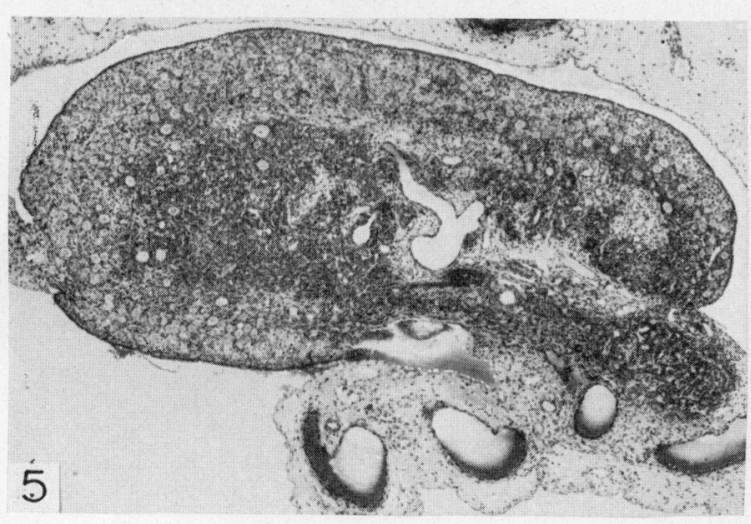

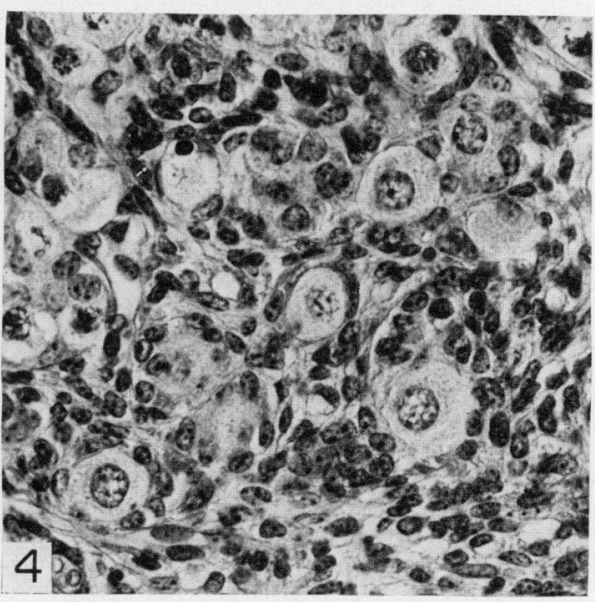

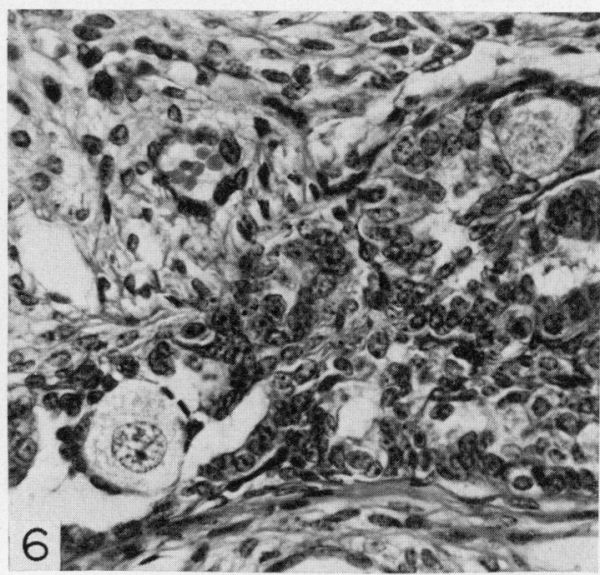



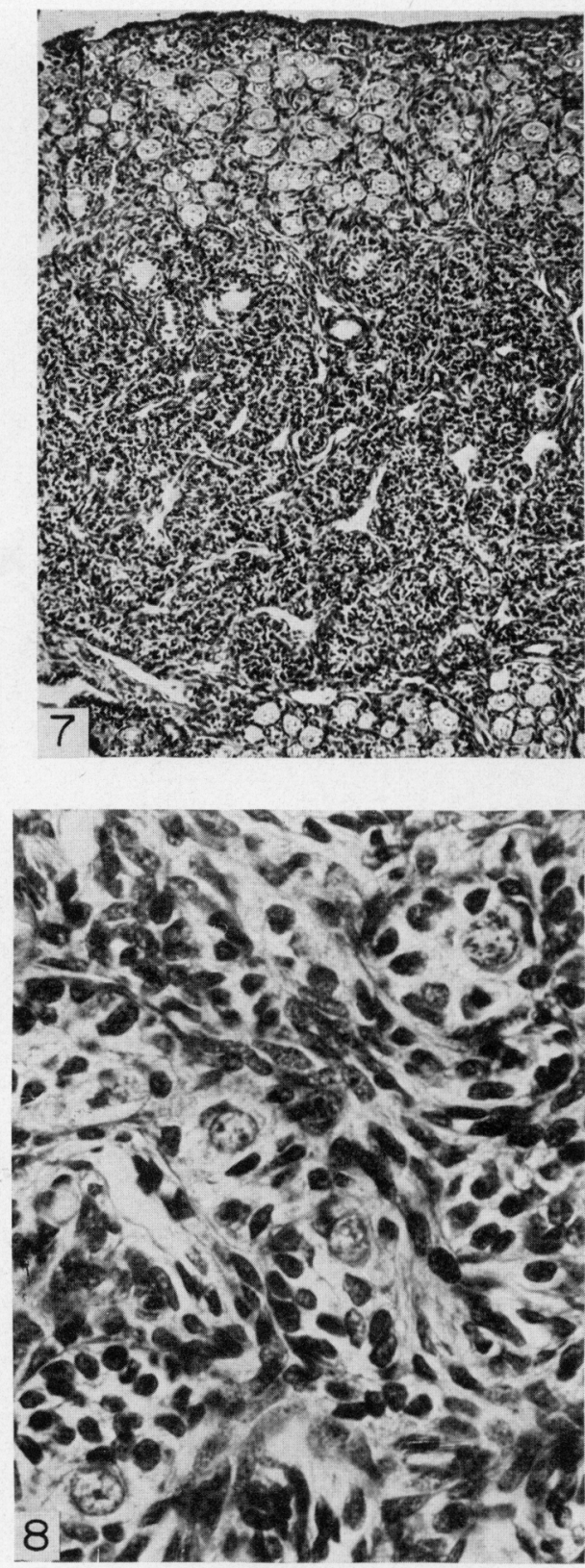

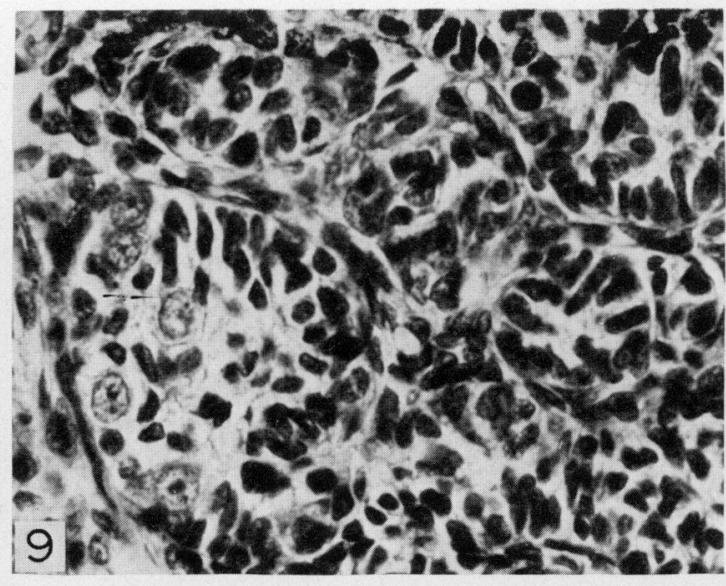

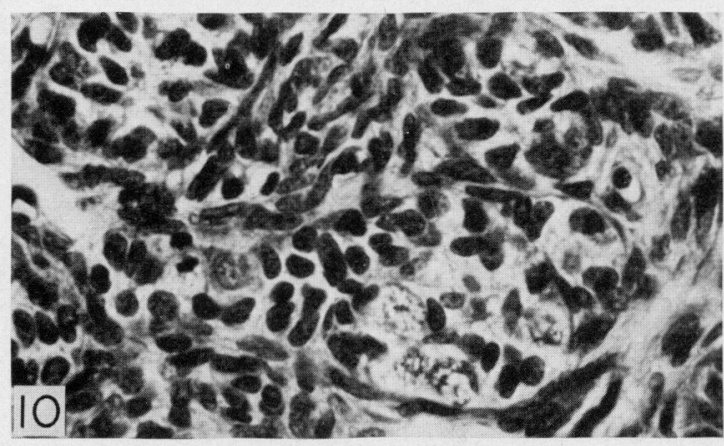

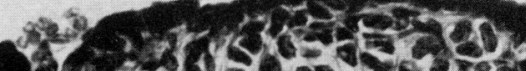

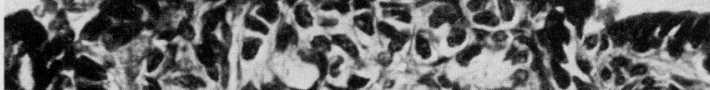

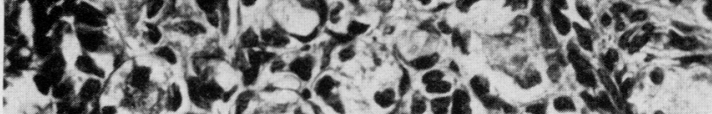

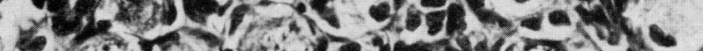

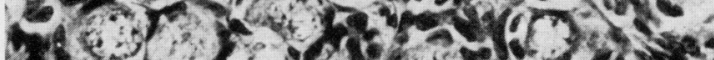

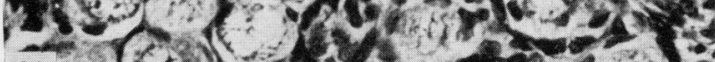

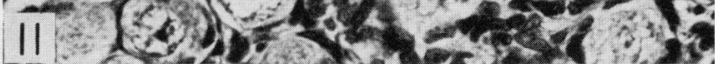

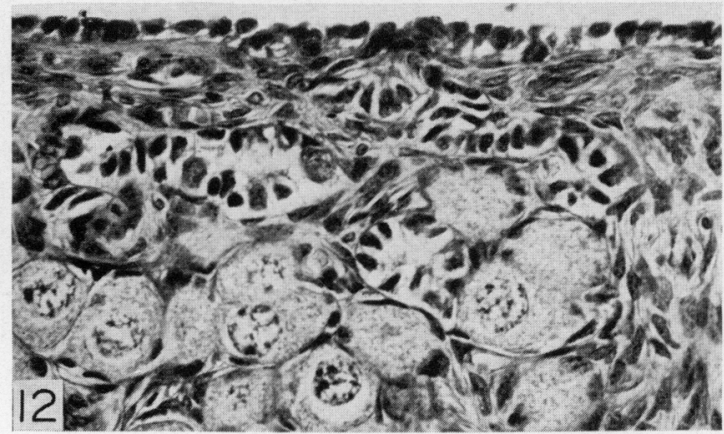


medulla. In this material the 24-day ovary was similar to the 20-day one except for some further growth of the rete. In ovaries at both ages the cortex consisted mainly of primordial follicles; some, near the medulla, showed cuboid or transitional pregranulosa cells. Other growing follicles already had one to two layers of pregranulosa cells. By 25 days the rete was fully developed and consisted of a compact group of tubules, the hilar rete near the end of the elongated ovary, and an extensive network of more dispersed tubules ramifying in the medulla (Pl. 2, Fig. 7). Although these were sometimes in contact with primordial or growing follicles there was no evidence that they contributed to either. Some follicles with one to two layers of pregranulosa cells were asymmetrical or pear-shaped, as in the guinea-pig, and mitotic figures were rare, but there were only doubtful indications of actual stromal attachment. Cell nuclei of the medullary rete tubules tended to be smaller than those of early granulosa cells but the two types were not always distinguishable.

Oocytes could frequently be observed in the medullary rete tubules and also less commonly in the medullary stroma. They differed clearly from the larger oocytes in primordial follicles and could be seen as part of the normal oocyte wastage occurring during and after meiosis (Pl. 2, Figs 8, 9 and 10). The 28-day ovaries examined were smaller than the younger ones but similar in follicular development and in the presence of oocytes in medullary rete tubules. Some tubules, however, had no lumen and appeared to be regressing. This process was further advanced in a 35-day ovary and the shrinking tubules would be unlikely to contribute to the many follicles with one or two layers of granulosa cells present at this time.

Characteristic of rabbit ovaries of 25, 28 and 35 days post partum, and those up to 55 days, were invaginations developing from the surface epithelium which formed short tubules, not unlike those of the rete, but separated from the latter by most of the ovarian cortex. A few contained small oocytes (Pl. 2, Figs 11 and 12). Such epithelial invaginations, not seen in guinea-pig ovaries, have been described by Neal \& Harrison (1958) and were discussed in detail as examples of abortive oogenesis in dogs of 54 days and older by Andersen \& Simpson (1973).

Examination of follicle formation and development in serially sectioned ovaries from the ferret, guinea-pig and rabbit has failed to confirm the conclusions of Byskov \& Lintern-Moore (1973) that rete tubules take part in follicle formation in the mouse. In the larger species, in which follicle formation occurs at a later stage of development, the increased size of the ovaries provided more material for examination. The medullary rete was well developed by the

\section{EXPLANATION OF PLATE 2}

Rabbit ovary at 25 days (Figs 7 to 11 ) and 28 days (Fig. 12).

FIG. 7. Part of a longitudinal section showing the cortex with primordial follicles and massed hilar rete tubules in the medulla. $\times 84$.

Figs 8, 9 and 10. Medullary rete tubules containing oocytes smaller than those of primordial follicles. Serial sections showed no evidence of follicle development in these areas. $\times 468$.

Fig. 11. Ingrowing surface epithelium. $\times 332$.

Frg. 12. Tubules from surface epithelium with developing oocytes. $\times 332$. 
time meiosis was ending and the first primordial follicles forming - a time when large numbers of oocytes in various meiotic stages are degenerating. Some degenerate in situ, others can be seen in the stroma and rete tubules of the medulla, especially in the ferret and rabbit. They occur similarly in the guineapig, in which the medullary rete tubules were fewer and larger. Such postmeiotic, surplus oocytes could not be confused with the larger ones in primordial follicles.

In the next stage of follicular differentiation there is an increase in diameter and a transition from flattened to cuboid pregranulosa cells. In the ferret few follicles enlarged and none had two layers at 4 weeks post partum. In guinea-pig and rabbit, however, some follicles started to grow almost immediately after their formation (Pl. 1, Figs 2, 3 and 4), but there were no histological indications of cell transfers to them from rete tubules, sometimes situated nearby. In the rabbit, regression of medullary rete tubules began about Day 28, at a time of follicle growth, and continued in the following weeks.

In conclusion, it may be stated that the rete takes no part in the formation of primordial follicles which arise in the cortex of the ovary, but develops in the hilar area and in the medulla. Further, the variations between species in the time at which the follicles begin to grow make it unlikely that rete tubules would normally be involved in the process, although in the rapidly changing ovary contacts may sometimes occur.

The hospitality and technical assistance of the A.R.C. Institute of Animal Physiology, Babraham, are gratefully acknowledged. The microphotographs were taken by Mr A. L. Gallup and the sections processed by Mr L. G. Jarvis.

\section{REFERENCES}

Andersen, A.C. \& Simpson, M.E. (1973) The Ovary and Reproductive Cycle of the Dog (Beagle). Geron-X Inc., Los Altos, California.

Воокночт, C.G. (1945) The development of the guinea-pig ovary from sexual differentiation to maturity. F. Morph. 77, 233-265.

Byskov, A.G. \& LinTERn-Moore, S. (1973) Follicle formation in the immature mouse ovary: the role of the rete ovarii. . Anat. 116, 207-217.

Deanesly, R. (1970) Oogenesis and the development of the ovarian interstitial tissue in the ferret. J. Anat. 107, 165-178.

IoAnNou, J.M. (1964) Oogenesis in the guinea-pig. F. Embryol. exp. Morph. 12, 673-691.

Конn, А. (1926) Uber den Bau des embryonalen Pferdeeierstockes. Z. ges. Anat. 79, 366-390.

Neal, E.G. \& Harrison, R.J. (1958) Reproduction in the European badger (Meles meles L.). Trans. zool. Soc. Lond. 29, 67-131.

Peters, H. (1973) Development and atresia of follicles in the immature mouse. Annls Biol. anim. biochim. Biophys. 13, 167-176.

Peters, H. \& Pedersen, T. (1967) Origin of follicle cells in the infant mouse ovary. Fert. Steril. 18, 309-313.

Peters, H., Levy, E. \& Crone, M. (1965) Oogenesis in rabbits. F. exp. Zool. 158, 169-179.

Sauramo, H. (1954) Histology and function of the ovary from the embryonic period to the fertile age. Acta obstet. gynec. scand. 33, Suppl. pp. 23-25.

TORREY, T.W. (1947) The development of the urino-genital system of the albino rat. III. The urinogenital union. Am. F. Anat. 81, 139-153. 